\title{
Determination of lymphocyte subgroups and activation status of them with flow cytometry at the time of diagnosis in COVID-19 patients
}

\author{
İhami BERBER ${ }^{1}$, Nurcan Kirici Berber ${ }^{2}$, Ahmet Sarici² ${ }^{2}$ Aslı Yıldırım³ ${ }^{3}$ Özlem Çağaşar ${ }^{3}$, \\ Harika Bag ${ }^{4}$, Burhan Turgut ${ }^{5}$, Yasir Furkan Çağın ${ }^{6}$, mehmet ali erkurt ${ }^{2}$, and Ozkan Ulutas ${ }^{7}$ \\ ${ }^{1}$ Inonu University School of Medicine \\ ${ }^{2}$ Affiliation not available \\ ${ }^{3}$ Malatya Turgut Ozal Universitesi \\ ${ }^{4}$ Inonu Universitesi \\ ${ }^{5}$ Namik Kemal Universitesi Tip Fakultesi \\ ${ }^{6}$ İnönü Üniversitesi Tıp Fakültesi Araştırma Hastanesi \\ ${ }^{7}$ Inonu University
}

June 23, 2021

\begin{abstract}
Background: Although changes of the main lymphocyte subsets (T cells, T helper, T cytotoxic, B cells, NK cells) and lymhocyte activation status in COVID-19 patients have been reported, the results of the studies differ each other. Therefore, we aimed to determine lymphocyte subgroups and activation status of them with flow cytometry at the time of diagnosis in COVID-19 patients and examine the relation of them with disease stage and length of hospital stay. Methods: Fourty patients included in the study were compared with the age and sex matched 40 healthy controls. COVID-19 patients were divided into 2 groups as mild and severe stage disease. Flow cytometry assay was performed to examine the numbers of lymphocyte subsets and activation status of them. Total lymphocyte count was calculated and CD45, CD3, CD4, CD8, CD19, CD27, CD38, CD56, CD57, IgD were studied on lymphocyte gate. T helper / $\mathrm{T}$ cytotoxic rates and length of hospital stay were recorded. Results: The patients' CD3 $(+) \mathrm{CD} 4(+)$ ( $\mathrm{T}$ helper) count and CD27 expression on $\mathrm{T}$ cells counts were significantly lower, and CD57 expression on $\mathrm{CD} 3(+) \mathrm{CD} 8(+) \mathrm{T}$ cytotoxic cells were significantly higher $(\mathrm{p}<0.05)$ than control gruop. When the patients were divided into mild and severe stages, it was observed that CD38 expression on $\mathrm{T}$ cells were significantly lower in severe stage patients $(\mathrm{p}<0.05)$ Total lymphocyte count and CD3 $(+) \mathrm{T}$ lymphocyte count were negatively correlated with the lengt of hospital stay as statistically significant $(\mathrm{p}<0.05)$. Conclusion: Our data showed that the SARS-CoV-2 primarly effects on $\mathrm{T}$ lymphocytes. It was thought that this effect occured by impairment of development and activation of $\mathrm{T}$ lymphocytes. There are some discordances among the studies on T lympocytes in the literature. Studies with more patients are needed to make this information more reliable.
\end{abstract}

\section{Hosted file}

Article Text.docx available at https://authorea.com/users/421344/articles/527416determination-of-lymphocyte-subgroups-and-activation-status-of-them-with-flow-cytometryat-the-time-of-diagnosis-in-covid-19-patients

\section{Hosted file}


Figures.docx available at https://authorea.com/users/421344/articles/527416-determinationof-lymphocyte-subgroups-and-activation-status-of-them-with-flow-cytometry-at-the-timeof-diagnosis-in-covid-19-patients

\section{Hosted file}

Table 1.docx available at https://authorea.com/users/421344/articles/527416-determinationof-lymphocyte-subgroups-and-activation-status-of-them-with-flow-cytometry-at-the-timeof-diagnosis-in-covid-19-patients

\section{Hosted file}

Table 2.docx available at https://authorea.com/users/421344/articles/527416-determinationof-lymphocyte-subgroups-and-activation-status-of-them-with-flow-cytometry-at-the-timeof-diagnosis-in-covid-19-patients

\section{Hosted file}

Table 3.docx available at https://authorea.com/users/421344/articles/527416-determinationof-lymphocyte-subgroups-and-activation-status-of -them-with-flow-cytometry-at-the-timeof-diagnosis-in-covid-19-patients 